A N N A L E S

U NIVERSITATIS MARIAE CURIE-SKŁODOWSKA

LUBLIN - POLONIA

VOL. LXIII, 2

SECTIO C

2008

\title{
ELŻBIETA SROKA
}

Department of Marine Ecology and Environmental Protection, Agricultural Unversity of Szczecin, Kazimierza Królewicza 4D, 71-550 Szczecin, e-mail: elzbieta.sroka@fish.ar.szczecin.pl

\section{Ecological structure of macrozoobenthos in Lake Miedwie in 2005}

Struktura ekologiczna makrozoobentosu jeziora Miedwie w 2005 r.

\section{SUMMARY}

Lake Miedwie is the largest freshwaters reservoir in the West Pomerania region. The 2005 study of Lake Miedwie involved benthos sampling at four sites in spring, summer, and autumn. In the biological samples were determined taxonomic structure and abundance of the zoobenthos. The test conducted revealed low numbers and low diversity of benthic fauna at all sites. In the entire season of testing true fly larvae Diptera dominated at sites 1, 2 and 3, while water mites Hydracarina were the dominant at site 4 .

\section{STRESZCZENIE}

Jezioro Miedwie jest największym zbiornikiem słodkowodnym na Pomorzu Zachodnim. Badania jeziora Miedwie prowadzono w 2005 roku na czterech stanowiskach, z których pobierano materiał biologiczny w sezonach: wiosennym, letnim i jesiennym. Następnie określono strukturę taksonomiczną i ilościową makrozoobentosu. Przeprowadzone badania wykazały małą liczebność i zróżnicowanie fauny dennej na wszystkich stanowiskach. W całym sezonie badawczym na stanowiskach 1, 2 i 3 dominowały larwy Diptera, natomiast na stanowisku 4 dominantem były Hydracarina.

Key words: Lake Miedwie, macrozoobenthos 


\section{INTRODUCTION}

Lake Miedwie, the sixth largest lake in Poland, is located between Stargard Szczeciński and Szczecin on the Pyrzycka Lowland. It is the largest freshwater reservoir in the Western Pomerania. The capacity of the lake basin amounts to 681 million $\mathrm{m}^{3}$. (1)

Miedwie is a deep, groove-like post-glacial lake, featuring an elongated, regular shape, without any larger breaks or incisions of its shoreline. There are no islands, clearly formulated peninsulas or bays. The southern part is slightly wider than the northern one. Nearly two thirds of Lake Miedwie constitutes the deepest cryptodepression in Poland. The deepest point of the lake bed lies $29.8 \mathrm{~m}$ below the sea level.

The Płonia river flows through the lake. Furthermore, it is fed by the waters of: the Ostrowica, the Gowienica Miedwiańska, the Miedwianka and numerous drainage ditches. The inflow of underground waters is estimated at $16 \%$.(7)

The terrain closest to Lake Miedwie is flat or rolling countryside used as fields, meadows and pastures. The area has been early and densely occupied with highly developed agriculture. 10 villages are located on the lake margins.(3)

In the summertime the reservoir is used extensively by tourists.

Since 1976, the lake has been used by supply water for the city of Szczecin. Tests of Lake Miedwie was conducted in order to determine the current state of water purity.

\section{MATERIAL AND METHODS}

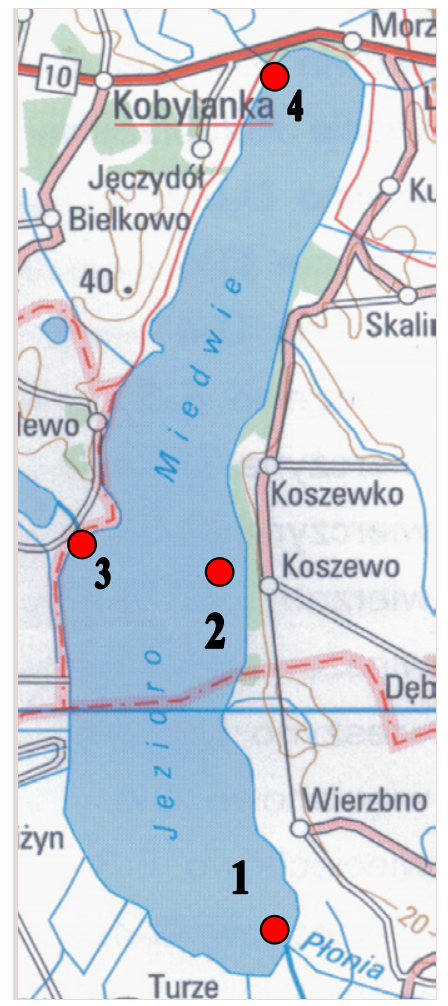

The research of Lake Miedwie in 2005 was conducted at four sites:

1 - by the river Płonia inflow,

2 - off the village of Koszewo,

3 - at Miedwie water discharge into the Płonia,

4 - by the river Miedwianka inflow. (Fig. 1.)

Fig. 1. Location of sampling sites 
Biological samples were taken with a van Veen grab (area of $0.0612 \mathrm{~m}^{2}$ ) from the selected sites, on the following dates: 11.04.2005, 28.05.2005, 11.07.2005, 07.09.2005, 30.11.2005.

At each site 3 sub-samples of bottom sediments were taken. The collected material was flushed through a sieve of a mesh size equal to $0.5 \mathrm{~mm}$ and was conserved in $70 \%$ ethyl alcohol, contaminated with hibitan. Subsequently, taxonomic and qualitative structure of macrozoobenthos was determined.

\section{RESULTS AND DISCUSSION}

In the research material of macrozoobenthos the sampled 13 taxa were determined, which belonged to: oligochaetes Oligochaeta, leeches Hirudina, scuds Amphipoda, mayfly larvae Ephemeroptera, true fly larvae Diptera, caddisfly larvae Trichoptera, water mites Hydracarina, mussels Bivalvia.

Average congestion of the total bottom fauna oscillated between 33-834 ind. $\mathrm{x} \mathrm{m} \mathrm{m}^{-2}$.

The macrozoobenthos data showed quantitative and qualitative differences beetwen both the sampling sites and the limnological seasons. (Fig. 2)

The highest taxa congestion in the entire cycle of research was found at site 1. Despite the highest congestion, the site featured the lowest species diversity (3 taxa), whereas the greatest species variety was recorded at site 3 (7 taxa).

In July an invasive species of scuds Pontogammarus robustoides was observed at site 3 . It is a relatively large and aggressive scud, which successfully hunts other tiny invertebrates (Oligochaeta, Chironomidae etc.). As an eruotypical and omnivorous species it may constitute a competition and a threat to the local benthofauna, also to the native species of Amphipoda, e.g. Gammarus lacustris. (2)

In September bottom fauna was only observed at site 4 in the number of 717 ind. $\mathrm{xm}^{-2}$, whereas at the remaining sites no taxon was found. (Fig. 2)

At sites 1, 2 and 3 true fly larvae Diptera dominated in the entire research season, constituting from $80.4 \%$ to $96.7 \%$ of the bottom fauna congestion. At site 4 water mites Hydracarina were the dominant, whose share amounted to $43.2 \%$. (Fig.3)

The percentage share of the other bottom macrofauna representatives at particular sites was much lower: oligochaetes Oligochaeta $-3.3-17.4 \%$; leeches Hirudina $-3-8.5 \%$; scuds Amphipoda - 2.8\%; mayfly larvae Ephemeroptera $7.2 \%$ and caddisfly larvae Trichoptera $-2.2 \%$.

Comparing an average congestion of bottom fauna from the lake under analysis in 2005 with the results obtained in 2003, a large decrease of the average congestion was recorded at all stations. There was also a species composition impoverishment from 21 taxa to 13. (6) 

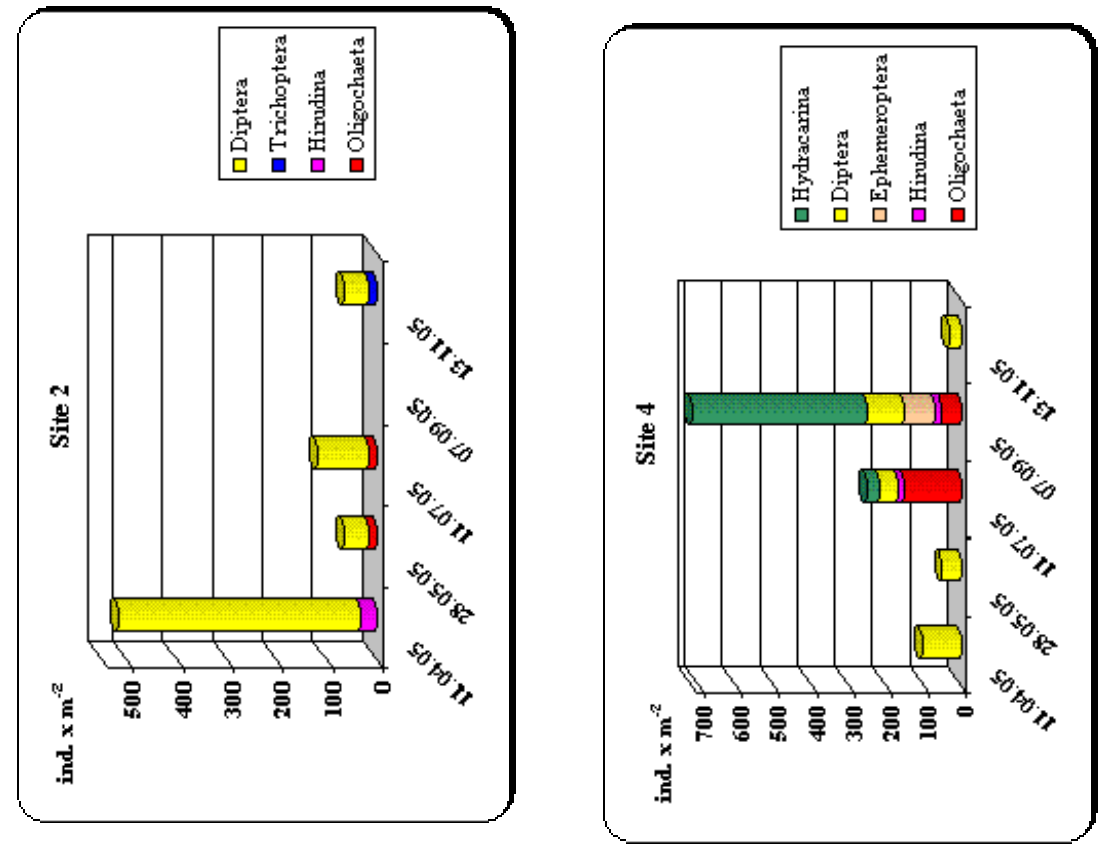

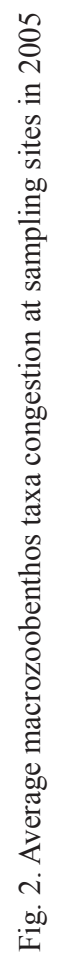
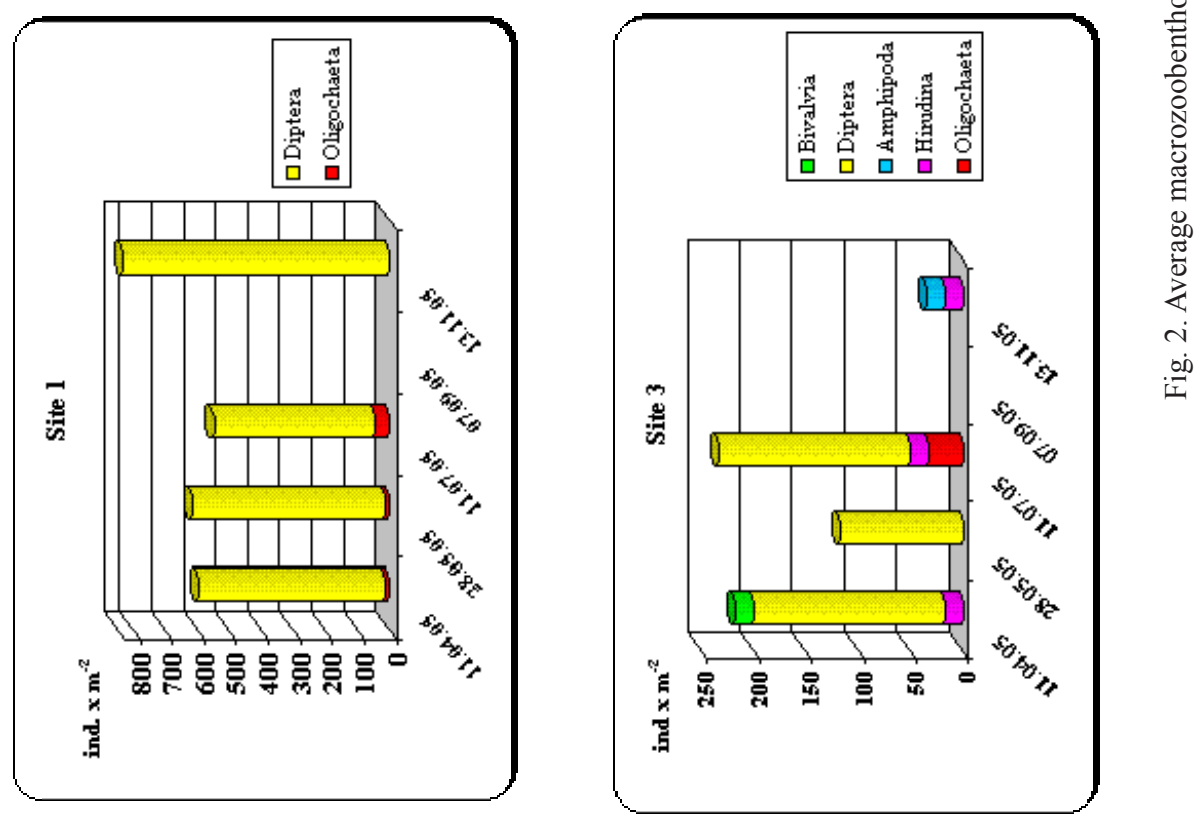


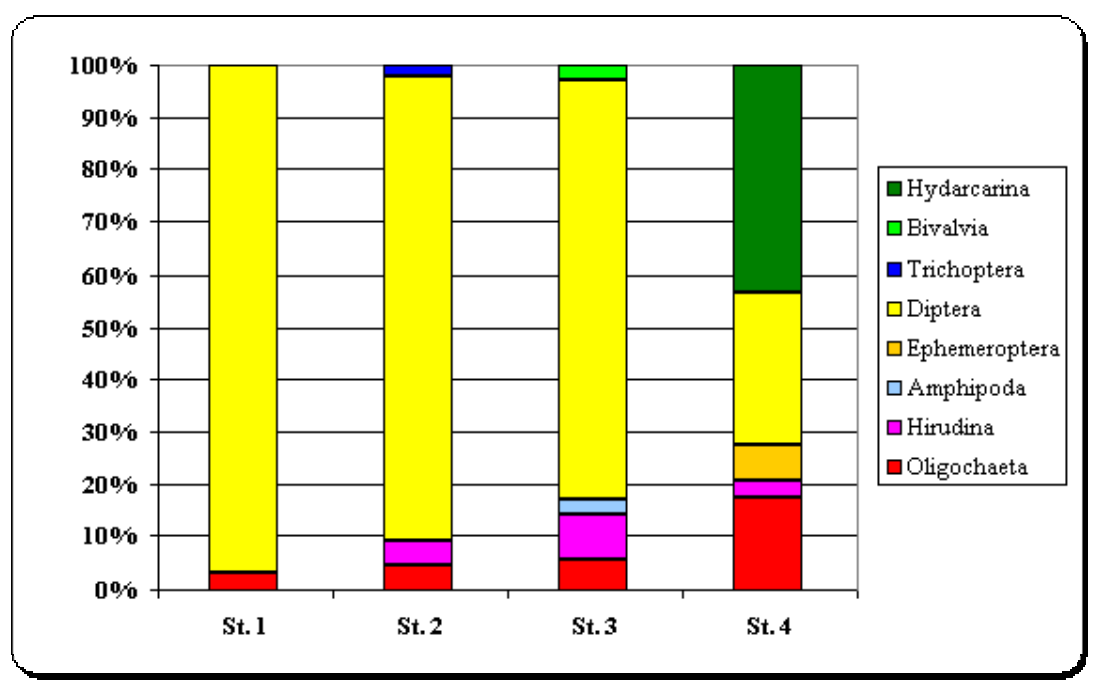

Fig. 3. Dominance structure of macrozoobenthos at particular sites in 2005

In 2005 snails Gastropoda were not found, while previously they were represented by the species of: Viviparus viviparus and Radix auricularia. There were also no representatives of mussels Bivalvia - the species of: Dreissena polymorpha and Bithynia tentaculata, only Anodonta anatina was found (site 3).

One of the factors influencing the qualitative-quantitative development of bottom organisms is water pollution. (4) At present the following aspects affect the quality of Lake Miedwie waters:

- the inflowing waters from two strongly eutrophicated lakes of Płoń and Będgoszcz,

- pollution from the villages which still do not have sewage system,

- insufficient reduction of biogenic compounds in urban water treatment plants located in: Koszewo, Skalin, Barnim and Wójcin,

- pollution from previous years deposed in bottom sediments,

- pollution from the area carried through a system of drainage ditches from water-logged areas and runoffs from the territories that are intensively farmed.

According to the analysis of water quality, Lake Miedwie falls into water purity class II. (5) However, the drop in species variety and macrozoobenthos congestion may constitute a proof of deteriorating environment conditions in this reservoir. 


\section{REFERENCES}

1. Borkowski A. 1994. Jeziora szczecińskie. Centralny Ośrodek Informacji Turystycznej na zlecenie Urzędu Wojewódzkiego w Szczecinie. Szczecin, 110.

2. Grabowski M., Konopacka A., Jażdżewski K. 2007. Alien Crustacea in Polish waters - Amphipoda. Aquatic Invasions 2 (1): 25-38.

3. Filipiak J., Sadowski J. 1994. Jeziora szczecińskie. Zarys faktografii. Wydawnictwo AR, Szczecin, 259.

4. Obolewski K., Gąska B. 2006. Bottom macrofauna of eutrophical Lubowidzkie Lake on summer stagnation period. Słupskie Prace Biologiczne 3: 57-72.

5. Praca zbiorowa 2007. Raport o stanie środowiska w województwie zachodniopomorskim w latach 2004-2005. WIOŚ, Szczecin.

6. Sroka E. 2005. Hydrochemical conditions and taxonomic structure of macrozoobenthos in Lake Miedwie in 2003. Ecological Chemistry and Engineering 12 (4) 451-456.

7. Szyper H., Gołdyn R. 1990. Studium ochrony jeziora Miedwie jako źródła wody do picia dla Szczecina. IGPiK, Poznań. 